\title{
Effect of the helix angle on a cutting edge of the milling cuter in the milling of aluminum alloy AlZn5.5MgCu
}

\author{
JAN BUREK \\ MARCIN PLODZIEŃ \\ ARTUR SZAJNA \\ JAROSŁAW TYMCZYSZYN *
}

\begin{abstract}
Dr hab. inż. Jan Burek, prof. PRz (jburek@prz.edu.pl)https://orcid.org/0000-0003-2664-5248 - Katedra Technik Wytwarzania i Automatyzacji, Wydział Budowy Maszyn i Lotnictwa, Politechnika Rzeszowska im. Ignacego Łukasiewicza, Polska

Dr inż. Marcin Płodzień (plodzienprz.edu.pl) https://orcid.org/0000-0001-8369-3604- Katedra Technik Wytwarzania i Automatyzacji, Wydział Budowy Maszyn i Lotnictwa, Politechnika Rzeszowska im. Ignacego Łukasiewicza, Polska

Mgr inż. Artur Szajna (a.szajna@prz.edu.pl) https://orcid.org/0000-0002-3820-7272- Katedra Technik Wytwarzania i Automatyzacji, Wydział Budowy Maszyn i Lotnictwa, Politechnika Rzeszowska im. Ignacego Łukasiewicza, Polska

Mgr inż. Jarosław Tymczyszyn (j.tymczyszyn@prz.edu.pl),https://orcid.org/0000-0003-2972-5112- Katedra Technik Wytwarzania i Automatyzacji, Wydział Budowy Maszyn i Lotnictwa, Politechnika Rzeszowska im. Ignacego Łukasiewicza, Polska
\end{abstract}

The article presents the influence of the angle of inclination cutting edge milling cutter on the milling process of AlZn5.5MgCu aluminum alloy. The study was carried out for two flute mills, three blades with different angle of inclination of the cutting edge. In experimental investigations, the components of cutting forces and surface roughness parameters were registered.

KEYWORDS: milling, aluminum, milling cutter

\section{INTRODUCTION}

AlZn5.5MgCu aluminum alloys are commonly used in the aviation industry - most often for hull structural elements (frames). Currently, these constructions are usually made of one block, which means that even $90 \%$ of the material must be removed during the cutting process [1]. Therefore, machining of such elements is carried out by the method of HPC (high performance cutting). High values of cutting speed and feedrates as well as depth of cut in HPC machining, as compared to conventional machining, require proper macro- and microgeometry of the tool [2]. In the HPC milling process, the basic problems are the shape of chips and the way they are removed, which depends, among others, on cutting edge geometry. Due to the fact that the milling cutter works mainly with a cylindrical surface, an important parameter of the milling macro-geometry is the value of the cutting edge inclination angle.

Manufacturers offer special geometry tools for machining the aluminum alloys. Differences in geometry result, among others, from the asymmetrical distribution of cutting edges and from the change in the inclination angle $\lambda$ of the helical line of the cutting edge. Due to different heights of the helix of the cutting edges, chips with a variable cross-section are formed, which results in a change in the components of cutting force (feed $\mathrm{F}_{\mathrm{f}}$, normal to feed $\mathrm{F}_{\mathrm{fN}}$, axial $\mathrm{F}_{\mathrm{a}}$ ) [4].

The cutting force components are of great importance, especially when machining the thin-walled elements, such as frames in aircraft structures. The force component perpendicular to the surface being machined (force normal to feed $\mathrm{F}_{\mathrm{fN}}$ ) can cause elastic or plastic deformation of the wall. These deformations result from the pressure exerted on the machined surface by the cutting edge of the tool.

Next, the influence of different inclination angles $\lambda$ of the cutting edge of the milling cutter on the course of the milling process is presented, depending on the change of cutting parameters. 


\section{Test conditions}

The study used samples made of aluminum alloy AlZn5.5MgCu. Milling was carried out on the vertical milling center DMC 635 V DECKEL MAHO from DMG (fig. 1). The cutting force components were measured using a Kistler force meter type 9121 and a 5019A charge amplifier, and the surface roughness measurements were made using a MarSurf M300 profilograph. Solid carbide, three-flute end mills with a diameter of $d=10 \mathrm{~mm}$, differing in the cutting edge inclination angle were used for the tests:

- with a constant inclination angle of the cutting edge $\lambda=45^{\circ}$ (fig. 2a),

- with a variable cutting edge inclination angle $\lambda=45^{\circ} \div 25^{\circ}$ (fig. $2 \mathrm{~b}$ ).

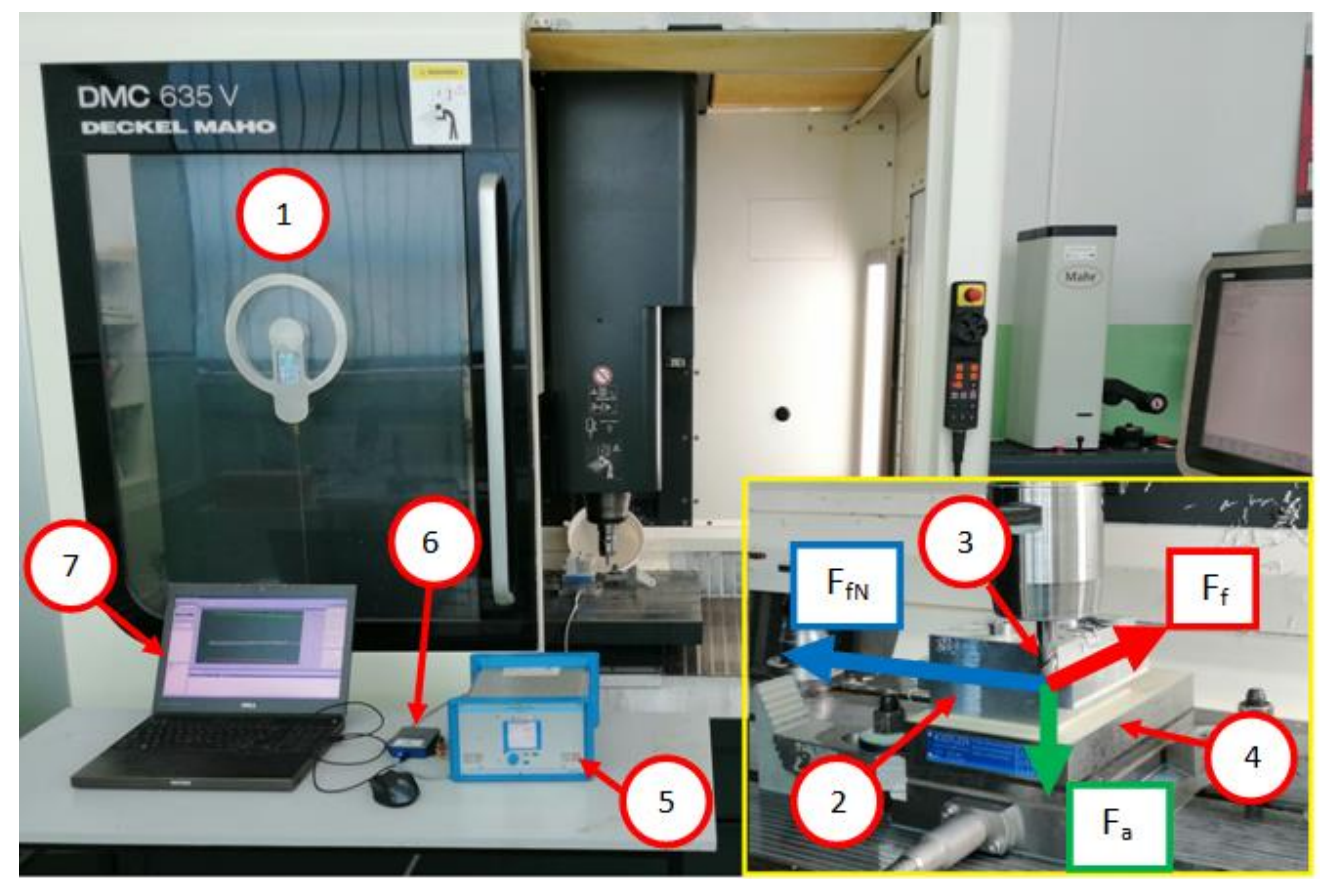

Fig. 1. Test stand: 1 - milling center DMC 635 V DEC-KEL MAHO by DMG, 2 - workpiece, 3 - tested milling cutters, 4 - dynamometer, 5 - amplifier, 6 - A/C converter, 7 - computer

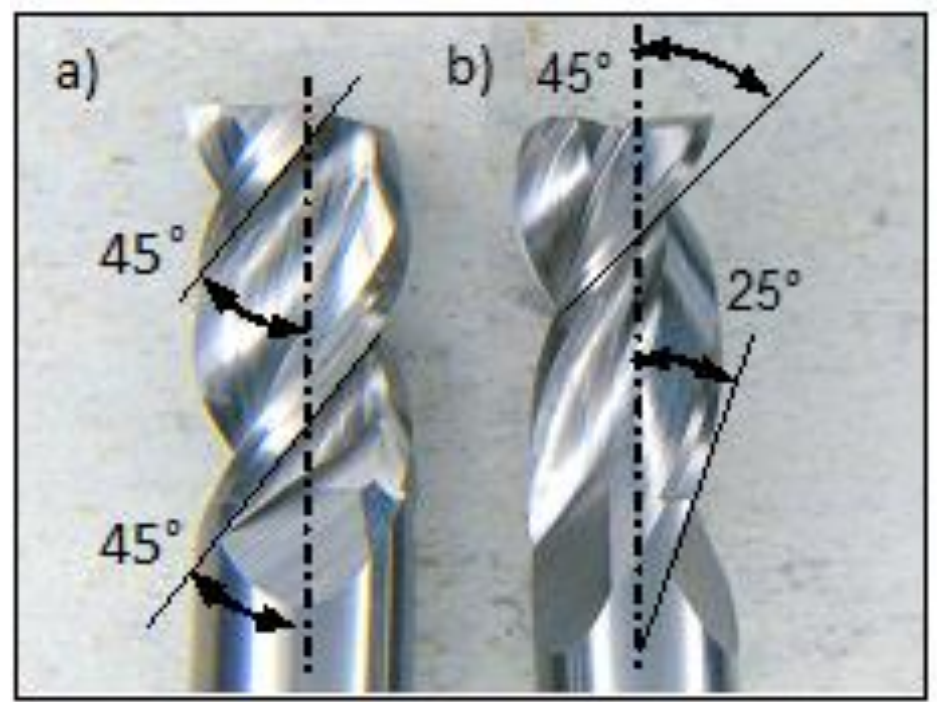

Fig. 2 . Tested cutters: a) with constant helix angle $\lambda=45^{\circ}$, b) with variable helix angle $\lambda=45^{\circ} \div 25^{\circ}$

\section{Results}

In the first test sample, constant technological parameters were adopted: cutting depth $a_{p}=10 \mathrm{~mm}$, cutting speed $v_{c}=200 \mathrm{~m} / \mathrm{min}$ and cutting width $a_{e}=3 \mathrm{~mm}$. The feed per tooth was changed $f_{z}=0.04 ; 0.06 ; 0.08 ; 0.1$ $\mathrm{mm} /$ tooth. Studied relationships of the influence of feed per tooth $f_{z}$ on the components of cutting forces for the tested tools are shown in fig. 3. 

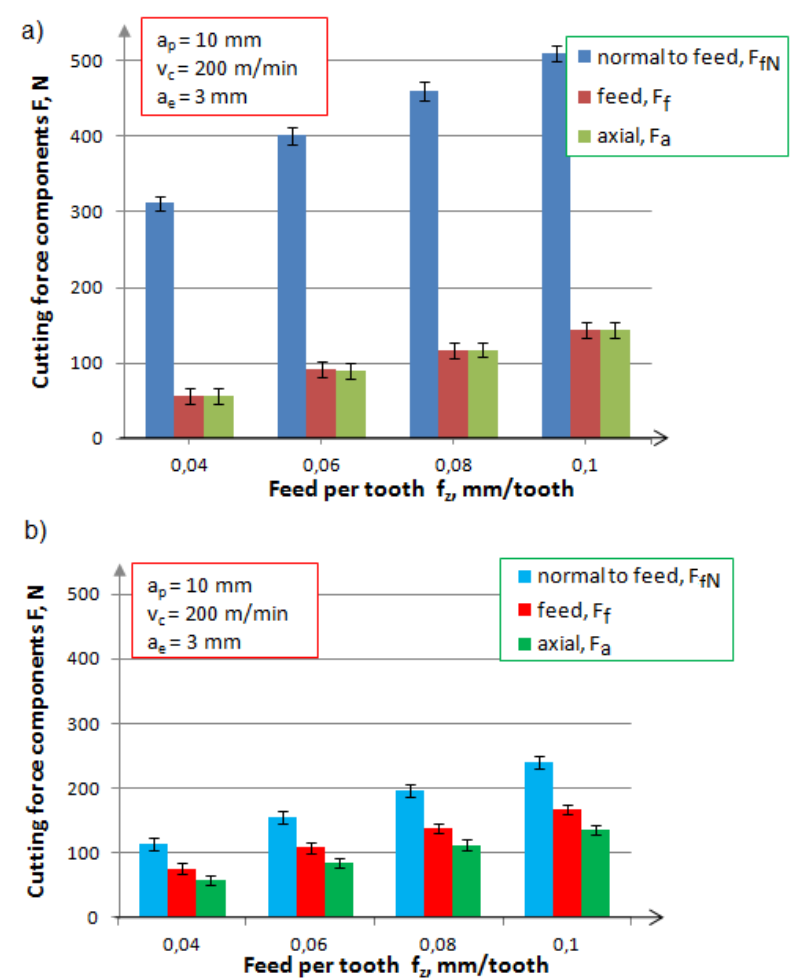

Fig. 3. Components of cutting forces depending on the feed per tooth $f_{z}$ for the milling cutter: a) with a constant helix angle $\lambda=45^{\circ}$, b) with a variable helix angle $\lambda=45^{\circ} \div 25^{\circ}$

One can notice much lower values of the cutting force components during machining with a milling cutter with a variable cutting edge inclination angle $\lambda$. Value of the normal to feed component force $\mathrm{F}_{\mathrm{fN}}$ for a milling cutter with a fixed angle $\lambda$ was at the level of $\mathrm{F}_{\mathrm{fN}}=300 \div 500 \mathrm{~N}$, the force feed component reached the values of $F_{f}=50 \div 150 \mathrm{~N}$, while the axial cutting force $F_{a}=50 \div 150 \mathrm{~N}$. For a milling cutter with a variable cutting edge inclination $\lambda$, the normal to feed component force $F_{\mathrm{fN}}$ is more than twice lower in relation to the force occurring during machining with a constant angle milling cutter $\lambda$.

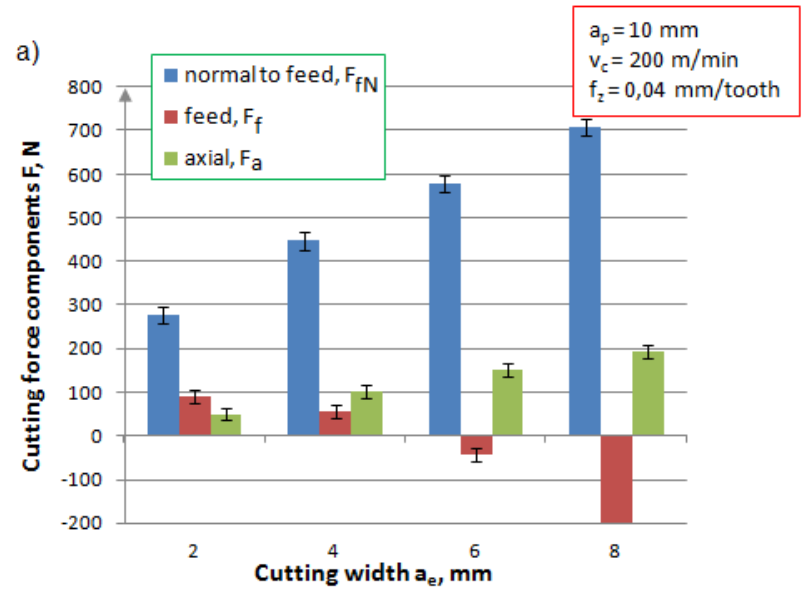

b)

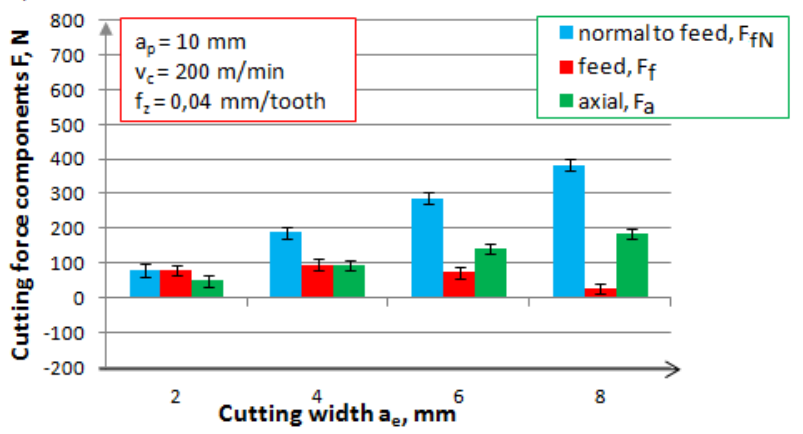

Fig. 4. Components of cutting forces depending on the cutting width $a_{e}$ for a milling cutter: a) with a constant helix angle $\lambda=45^{\circ}$, b) with a variable helix angle $\lambda=45^{\circ} \div 25^{\circ}$ 
a)

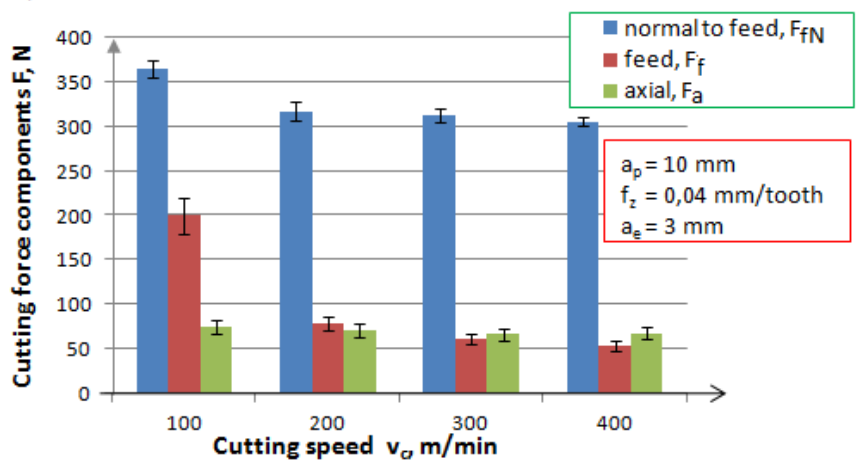

b)

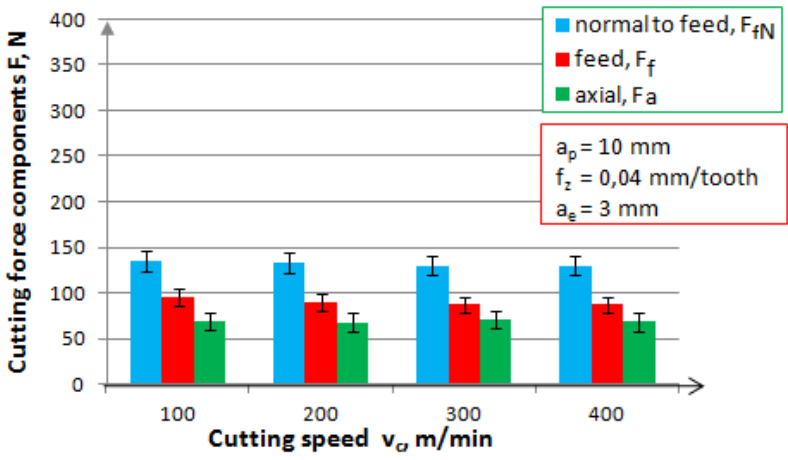

Fig. 5. Components of cutting force depending on the cutting speed $v_{c}$ for a milling cutter: a) with constant helix angle $\lambda=45^{\circ}$, b) with a variable helix angle $\lambda=45^{\circ} \div 25^{\circ}$

In the second test sample, constant technological parameters were adopted: cutting depth $a_{p}=10 \mathrm{~mm}$, cutting speed $v_{c}=200 \mathrm{~m} / \mathrm{min}$, feed per tooth $f_{z}=0.04 \mathrm{~mm} /$ tooth. The cutting width was changed to $a_{e}=2 ; 4 ; 6 ; 8$ $\mathrm{mm}$. The obtained dependencies of the influence of cutting width ae on the cutting force components are shown in fig. 4.

Analyzing the obtained results, a change in the direction of the feed force $F_{f}$ was observed for a milling cutter with a constant angle $\lambda$. The force $F_{f}$ direction is changed when the milling cutter works with a cutting width $a_{e}>50 \% \cdot d$. The feed force $F_{f}$ with a cutting width $a_{e}=80 \% \cdot d$ is approximately $200 \mathrm{~N}$. The normal to feed $\mathrm{F}_{\mathrm{fN}}$ and axial $F_{a}$ component force for both cutters show an increase in value during increasing the cutting width $a_{e}$.

In the third test sample, constant technological parameters were adopted: cutting depth $a_{p}=10 \mathrm{~mm}$, feed per tooth $f_{z}=0.04 \mathrm{~mm} /$ tooth and cutting width $a_{e}=3 \mathrm{~mm}$. The cutting speed $v_{c}=100$ was changed to 200; $300 ;$ $400 \mathrm{~m} / \mathrm{min}$. Results of the dependence of the influence of cutting speed $v_{c}$ on the components of cutting forces for the tested tools are shown in fig. 5.

As can be seen, there is a decrease in components of cutting force as the cutting speed $v_{c}$ increases. The normal to feed $F_{\mathrm{fN}}$ for a milling cutter with a constant angle $\lambda$ is approximately $300 \div 370 \mathrm{~N}$, and for a milling cutter with a variable angle $\lambda$ - approximately $140 \mathrm{~N}$. The other components of cutting force, i.e. $F_{f}$ and $F_{a}$, have similar values $(60 \div 100 \mathrm{~N})$.

Results of the influence of the angle of the cutting edge of the milling cutter on the surface roughness parameter $R a$ are shown in fig. 6.

After surface machining with a constant $\lambda$ cutter, the $R a$ parameter was twice as low as compared to a variable $\lambda$ cutter. An increase in the $R a$ parameter as a function of the cutting width can be seen for a cutter with a variable angle $\lambda$. The $R a$ parameter for a surface shaped with a constant $\lambda$ angle cutter remains in the whole range at approximately $0.18 \div 0.25 \mu \mathrm{m}$. The increase in the cutting width $a_{e}$ to the value of $80 \%$ of the tool diameter with a variable angle $\lambda$ caused the $R a$ parameter to increase to $1.12 \mu \mathrm{m}$.

For both milling cutters used, the surface roughness $R a$ tends to increase over the entire tested range of $f_{z}, a_{e}$ and $v_{c}$ parameters. Maximum value of $R a=1.44 \mu \mathrm{m}$ was achieved at cutting speed $v_{c}=400 \mathrm{~m} / \mathrm{min}$ when machining with a variable angle cutter $\lambda$. 

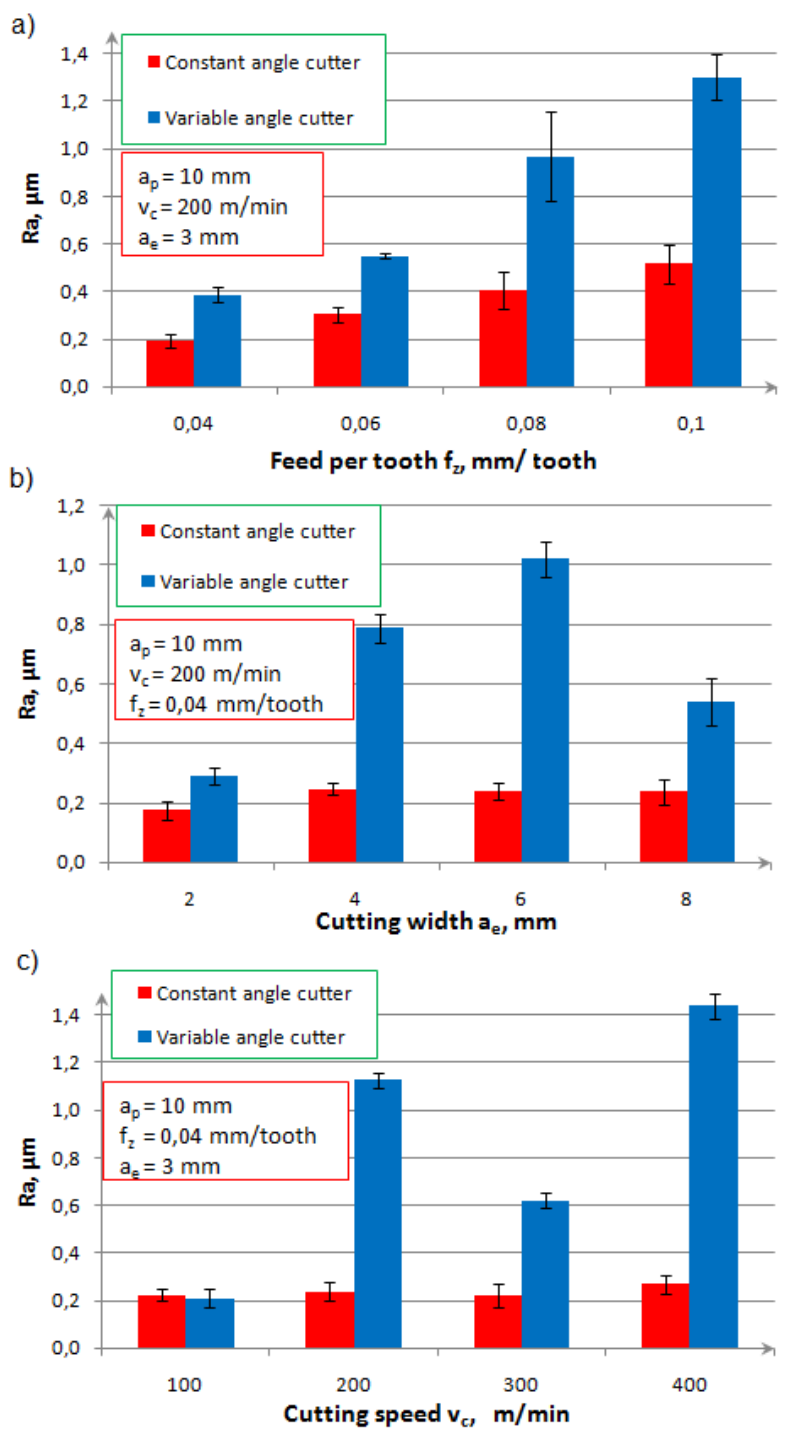

Fig. 6. Dependence of the surface roughness parameter $R a$ on: a) feed per tooth $f_{z}$, b) cutting width $a_{e}$, c) cutting speed $v_{c}$

\section{Summary}

Based on the research, it can be concluded that the use of tools with a variable angle of inclination of the cutting edge $\lambda$ significantly reduces the component of the normal to feed force $\mathrm{F}_{\mathrm{fN}}$, however, it leads to a greater surface roughness compared to the surface roughness after machining with a constant angle cutter $\lambda$. For this reason, milling cutters with a variable cutting angle $\lambda$ are suitable for high-performance roughing of aluminum, carried out at maximum cutting speeds and feed. In contrast, milling cutters with a constant cutting edge inclination angle $\lambda$ should be used for finishing.

\section{REFERENCES}

[1] Burek J., Żyłka Ł., Płodzień M., Buk J. „Wpływ zarysu ostrza freza na kształtowanie wiórów w wysokowydajnym frezowaniu stopu aluminium". Mechanik. 8-9 (2016): 1216-1217.

[2] Burek J., Żyłka Ł., Gdula M., Płodzień M. „Wpływ zarysu linii ostrza freza na siłę skrawania w procesie wysokowydajnej obróbki stopu AlZn5.5MgCu". Mechanik. 8-9 (2015): 275-284.

[3] Burek J., Żyłka Ł., Płodzień M., Sułkowicz P., Buk J. „Wpływ kąta pochylenia krawędzi skrawającej frezu na proces odprowadzania wiórów ze strefy skrawania”. Mechanik. 11 (2017): 962-964.

[4] Kuczmaszewski J., Zaleski K. „Obróbka skrawaniem stopów aluminium i magnezu”. Lublin: OWPL, 2015

[5] Obróbka skrawaniem i narzędzia skrawające, Praca zbiorowa pod red. W. Olszaka, K. Marchelki, Wyd. 1, Wyd. PS, Szczecin 1972.

[6] Grzesik W., „Podstawy skrawania materiałów metalowych”, Wydawnictwa NTW, 1998. 